\title{
PHYWE 超遠心機の機構と性能
}

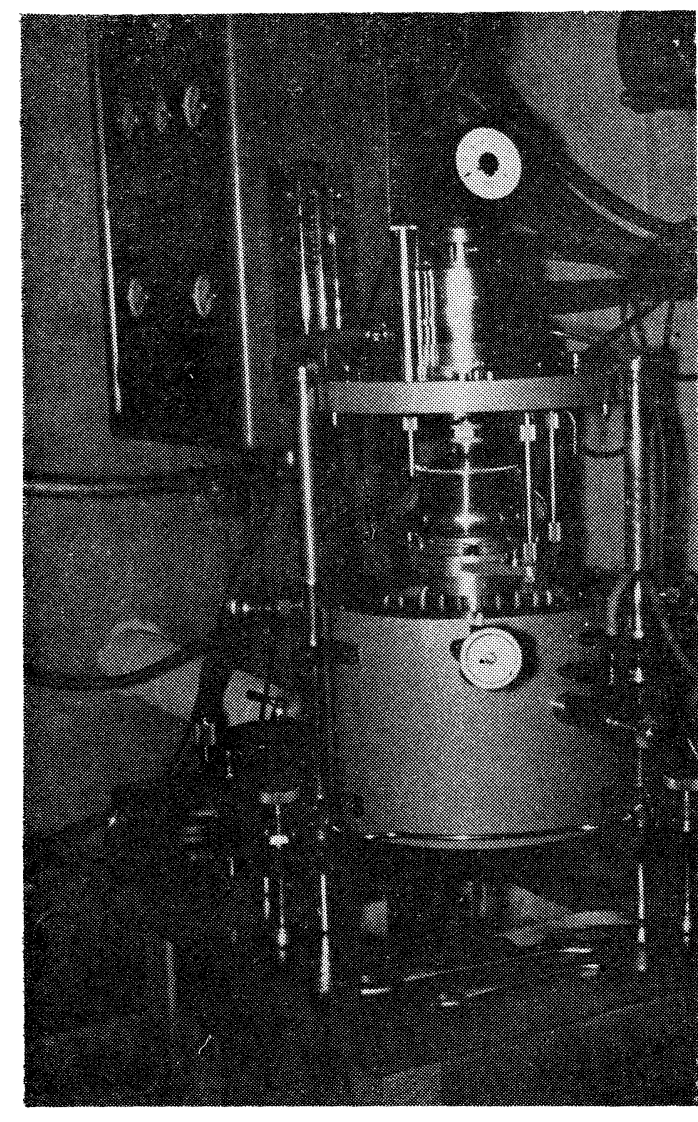

はしがき

超遠心機をもちいて高分子物犋の分子量を測定すると マらことは, 滲透圧, 光散乱度の浿定によるものとなら び非常に有效な方法である。特に，Svedberg 自身もい っているごとく1)，これから求められる分子量は，なん らの仮定なしに導き出された理論式をもとにしていると いう点から, 他の二者より一層基本的な方法ということ ができる。

しかし，残念なことに本法は機械自体の試作がおくれ たこと，またその価格が非常に高いことなどから, 数年 前まで，本邦研究者間で本機使用は全く望みなしのごと き感をさえいだかしめられていたのである。さいわいに して昭和 22 年來, 交部省の協力による総合研究や, こ こ数年來米國 SPINCO 社製超遠心機, ならびにドイッ PHYWE 社のものなどが輸入されるようになり, 特に後 者は当研究所に設置されるようになったので, 今後この 方面での知見の得られることが期待されているわけであ
写眞(左): 分離用ローターを

とりつけた超遠心機

(右): PHYWE 超遠心機
博

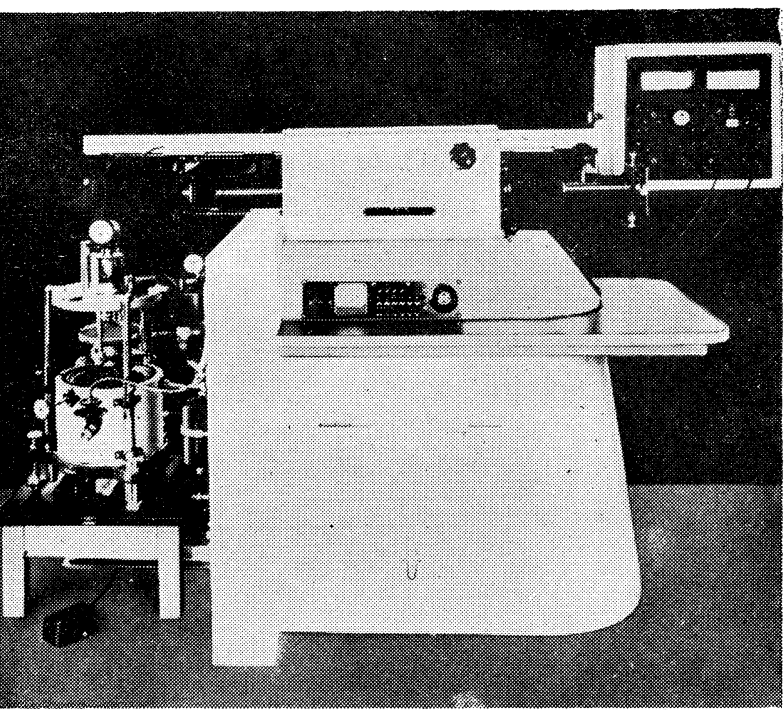

る。ここでは超遠心法の一般的理論はさておき， PHYWE 超遠心機の機構や性能を詳しくのべようと思う。特 に本機は, 米國 SPINCO 勍製超遠心機 (Model-E) が 電動機による㐘車增速法を探用しているのに対して, 空 氣タービン駆動法をつかっている点で, 本邦での試作に 多くの示唆をあたえらるものであろう。

\section{§ 1 PHYWE 超遠心機の譜系}

Svedberg が超遠心機を試作しはじめた 1925 年, フ ランスにおいて Heriot および Huguenard2) が円錐形 のコマの円錐面に刻目をつけ，これに圧搾宾氣を吹きつ けて趣転させると同時に空中に浮上させ, 軸受けをもち いることなく高速度回転をうることに成功した。円錐形 コマの超遠心機は回転数は $10^{5}$ r. p. m. にとれるよらに もなったが，その大きさ（ローターの直径）はたかだか 数 $\mathrm{cm}$ 程度以上のものを製作することは困難であり,し たがって, その分解能3) が低いため, 超遠心機としての 性能をこれ以上向上せしめることは困難であった。空氣 
タービン間接駆動方式の超遠心機は，このような難点を 打開するために Bauer およびPickels') により試作さ れた。これは上述のコマから細い軸をだし，この下に大 きなローターをとりつけ，これを圧搾空氣によるコマの 趣転および浮上により軸受けなしに趣転する考案であ る。

ここに述べようとする PHYWE 超遠心機は, このよ らな方式を探用したもので，Max Planck Institut の Schramm および Bergold ${ }^{5}$ ) によって試作され PHYWE 社に引きつがれたものである。1938 年頃より本格的に 製作がはじめられ, 当化学研究所へ輸入せられたものは 108 台目のものである。

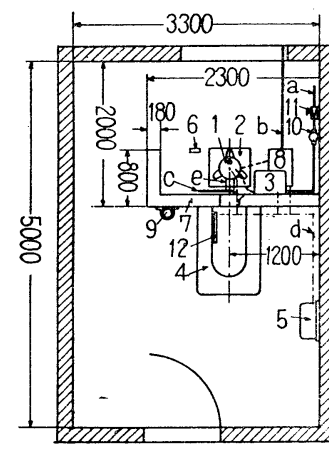

1: Vakuumkammer

2: Hocker

3: Hahnbatterie I

4: Optische Einrichtung

5: Messschalttafel

6: Fussschalter

\section{Prisma}

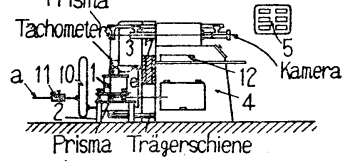

a: Druckluftleitung $11 / 4 "$ vom Kessel

b; Wasserstoff-Ableitung $1 / 2^{\prime \prime}$

c: Kuihlwasser $1 / 2$ "

d: Elektr. Leitungen

e: Schlauchleitungen

\section{7: Schutzwand}

8: Vakuumpumpe

9: Wasserstoff Flasche

10: Druckluftfilter

11: Druckminder-Ventil

12: Elektr. Verteilerschalttafel

第 1 図 Aufstellungsplan I für die Ultrazentrifuge

間接駆動方式を探用した空氣タービン超遠心機は，そ の構造が比較的簡單であるとともに高速回転につきまと う趣転軸受けの問題, ならびに菌車駆動の場合における ごとき歯車の熱, 騷音などの発生および摩籷などがない ために割合よい狀態を期待することができる。その上, ローターをとりかえることにより分離用にも併用できる 利点をもっていることなどなかなか便利なものである。

\section{$\S 2$ 超遠心機の全体的構造}

カット写偵右側および第1 日に PHYWE 超遠心機の 外観と部分を示す。第 1 図にあるごとく,まず 12.5 馬力 のコンプレッサーにより 10 氣圧まで圧縮された空氣は 1000 リッターの空氣タンクに 1 度溜められ, 図中 [a] なるパイプに接続される。压搾空氣は [II]なる減圧 弁 (Druckminderventil) を通り, 滤過器 (Druckluftfilter) [10]を通って Hahnbatterie 1 [3〕 とよばれる コック系の制御盤に入る。ここで圧䇽空氣は種々のコッ クによって各種の目的に供する分岐がなされる。

すなわちタービンを駆動するための空氣 (Treibluft), タービンを停止するための空氣 (Bremsluft) などがそ れである。

これらの空氣はゴム管によって〔1]なる覓空箱 (Vakuumkammer)一この中でローターが廻転する一の上蓋

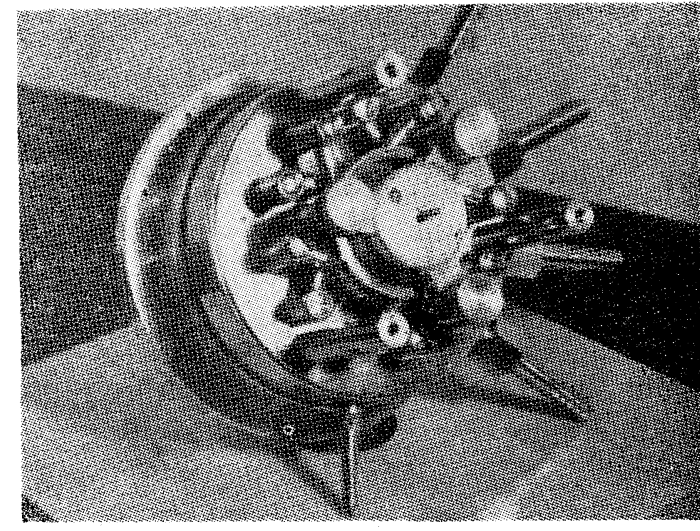

第 3 図 Triebwerk

にとりつけられた駆動部 (Triebwerk), すなわちタービ ンおよびこれに空氣をふきつけるための突起孔 (Düse) をもつ部分に扔くりこまれる。覓空箱 [1]は〔8]なる 眞空ポンプにより排氣され同時に, 水素ボンベ [9]から. 水素が 3 5 $\mathrm{mm} \mathrm{Hg}$ の圧力で吸引されて覓空箱を通り, 畺空ポンプで排出され，[b]なるパイプを通って空外に 放出される。水素を通ずるのは, 畺空箱の內壁に沿って 取付けられる冷却用蛇管と趣転するローターとの閒の熱 交換を行って, ローターの溫度を一定に保つためであっ て, これは Spinco 社の冷却が輻射のみによっている のと著しく相違する点である。〔4〕は光学系全部が組み 込まれた部分であり，光源水銀燈をはじめレンズ, プリ ズム, スリットおよび撮影用カメラなどを裝備している。 光学系に関しては後で辣しく述べる。

\section{§ 3 迴転駆動部}

ローターの廻転駆動機構を詳細に示す目的で第视 2 四を かかげる。これは大別して次の 3 つに分けることができ る。（i）駆動部 (Triebwerk) (第 3 図参照), (ii) 口 ーター (Rotor mit Zange), (iii) 防振軸受 (Dämpflager) である。

駆動部は [1]な る外被箱中にあり， Kopflager とよばれ るボールベアリング 〔2], タービン (Turbine mit Notlauflager） [3], 主軸受 (Hauptlager) [4] お よびこれを貫通する 径 $3 \mathrm{~mm}$ のドリルロ ッド (Welle) [5]か らなっている。 [3] なるタービンは衝動 式で上下各 36 個で, その方向が互に反 対向きのフラッチン グをつけ, タービン

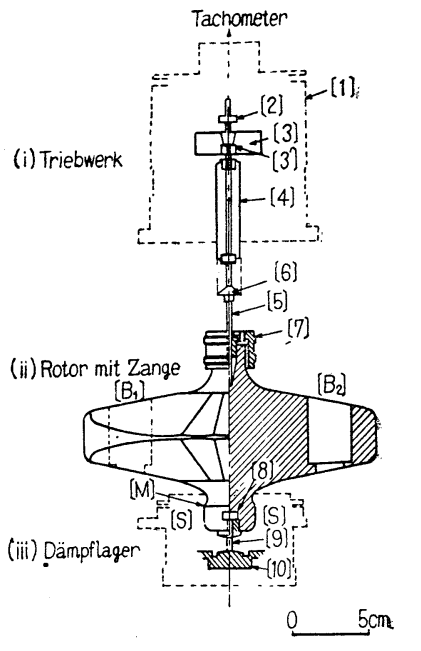

第 2 図 回転機構 
におけるバケットの役割をさせている。上部のバケット はブレーキを，下部は駆動のためのものである。このタ ービンの底部に接して, Hubluftplatte とよばれる板が あり(図では示されていない),ここには $0.5 \mathrm{~mm}$ 孔 が 6 個あけられており, 約 $5 \mathrm{~kg} / \mathrm{cm}^{2}$ の圧搾空氣は, こ の板の下部から吹き出されて, タービンを浮きあげ, こ こに空氣軸受 (Luftlager) を形成する。なお万一,ター ビンの底面と Hubluftplatte が面接触するようなことが あれば，完全に機械を破損するおうそがあるので，〔3】 なるボールベアリングが埋めこまれ (Notlauflager), こ のベアリングの底面は極くわずかタービンの底面より下 部につき出し, 両者の直接的な面接触を避けるようくふ うされている。〔4]なる主軦受は両端に図のごとき金属 片をもつ 1 つの円筒であり，この内側に約 $3 \mathrm{~kg} / \mathrm{cm}^{2}$ の 圧力でおし出された低粘度のスピンドル油を允満する。

軸の回転に伴って, 內部の油には遠心力と外部からの 圧力とが互に正反対に作用するから，ここに 1 つの油皮 膜が形成され，軸の㵎滑の外に真空箱と高圧宾氣による 駆動部とのパッキングを策礼た役目をする。なお，〔6] で示した䤵（つば）は主軦受〔4]からもれた油を飛散 せしめ, ローターが油で污れないために取付けられたも のである (Ölspritzring)。

ローターはその上部に备転䠳 [5]と結合せしめるた 奶のチャック (Zange) [7] と，下部にボールベアリン グ [8]を內藏している。[8]のアウター・レースは口 一ターの下部中心にあけられた孔にはめ达み固定され， そのインナー・レースには防振軖受 (iii) の中から笑出 した突起軸（Stifte）[9]がはまりこむ。ローターを含 沈回転系のもつ固有振動は, 軸 〔9]が防振軸受の底面に 3 個の防振ゴム片でささえられた板 [10]から突出して いるため,ここでほとんど吸收されるよう設計されてい る。またこの防振軵受 (iii) はローターの外側で自空箱 の上蓋に固定された支桂によって支えられている。

ローターには回転軸加ら $65 \mathrm{~mm}$ の位置に中心をもつ

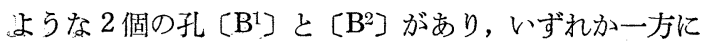
孫沈降させようとする溶液を入れる测定用セル (Mess:zelle), 他にはそのぶランス用セル (Gegenzelle) を挿 卆する。

ローターの下部に [M]で示した部分に磁石がとりつ 行られ，これは溫度によりその磁化度が大巾に变化する 特種なものである (temperaturabhängige Magnet)。一 方, 防振㟽受中の〔S]で示された部分にはコイルがお 胁れており，ロータ一の趣転に伴って，このコイルには， 感応電流が流れる。そして，この電流は迥転する磁石の 滋化度のある函数であるから, あらかじめ溫度で補正さ :れた目盛を有する電流計で，これを読めばローターそれ 自体の溫度を正確に知氙ことができる。(PHYWE 社特 許）ロータ一の溫度は, 分子量の算出に際して重要な役 割を演ずるから，本機の 1 つ利点は，この温度測定の 完全さと前述の强制冷却による定溫保持の優越性を挙げ :るべきであろう6)。

\section{$\S 4$ 迥転数の自衝制御}

沈降常数を正確に決定する上で, 溫度の一定といらこ と以外にさらに重姴な点は, 趣転数を正確に知り, かつ 測定時間中に一定であるといらことである。遠心加速度 注迴転数の自乘できくから，その誤差は倍加されるおそ れがある。PHYWE 超遠心機では, 第 2 圀に示した駆 動部（i）の外被箱〔1〕上にダイナモにより作動するタ

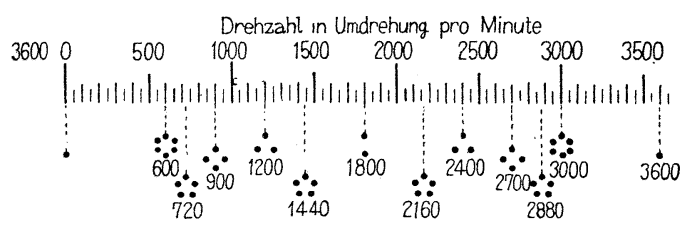

第 4 図 回転数測定用パターン

コメーターをとりつけ，この廻転軸とローターの椢転軸 とをゴム管で連結し，この出力電流を迴転数として目盛 った電流計でよみとる。電流計には指針の外に，いま 1 つ希望迴転数（Solldrehzahl）を示す指針があり，希望 趣転数をあらかじめこの指針で示しておくと，この指針 と電流計の指針とが接触したところで, リレー回路が作 動して駆動用空氣の圧力を低下させる。かくて $0.02 \sim$ $0.1 \%$ の範囲內で趣転数は自働制御される。

备転数の測定はブラウン管オッシログラフで行われ る。すなわちタコメーターには, ローターの椢転軸とゴ ム管で結合されたマグネットがあり，この周囲に互に位 相の $90^{\circ}$ 異なったように配置されたコイルがおかれて いる。マグネットの迴転によってコイル內に発電された 交番電流は, 各コイルの組合せごとで, その位相も $90^{\circ}$

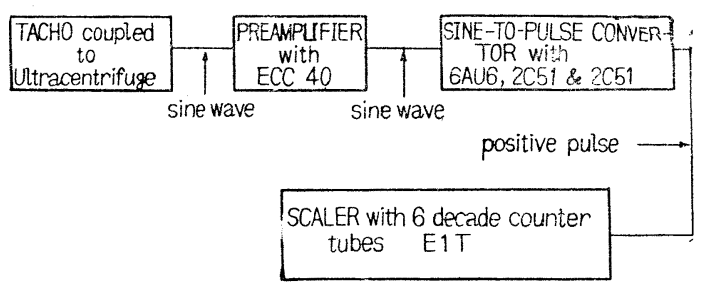

第 5 図 積分回転計ブロック図

ずれているから，これら 2 つ電流をオッシログラフの 垂直拉よび水平軸に入れてやると円の軦跡がえられる。 そしてその円の椢転角速度はローターの备転数に等し い。このような軌跡を電源の周波数で同期したパルス波 で変調してやると，第 4 図のようなパターンがブラウン 管上にあらわれ，これをもとに迴転数を決定する。この 計器は全部第 2 回 [5]に示された配電盤上に裝備され ている。

しかし，この測定法は本邦のごとき電源周波数の変動 の多、地域では誤差が大きく，また口ーター自身の呬転 にムラのあるとき，これを逐一追跡測定することは困難 である。SPINCO Model-E 遠心機では電源周波数を趣 転速度制御の基淮として使用しているが7)，これもまた 本邦では，その制御精度の良好結果はのぞみえない。こ のような点から，筆者および岡本は積分式迴転計を試作 
第 1 表

\begin{tabular}{|c|c|c|c|}
\hline Time (p.m.) & Time interval & $\begin{array}{l}\text { Total revolu- } \\
\text { tion numbers }\end{array}$ & $\mathrm{rpm}$ \\
\hline 6.45 & $\left.\begin{array}{l}6.48 \\
6.58\end{array}\right\} 10 \mathrm{~min}$ & 500862 & 50086 \\
\hline 7.00 & $\begin{array}{l}7.03110 \mathrm{~min} \\
7.13\end{array}$ & 500805 & 50081 \\
\hline 7.15 & $\left.\begin{array}{l}7.18 \\
7.28\end{array}\right\} 10 \mathrm{~min}$ & 500524 & 50052 \\
\hline 7.30 & $\begin{array}{l}7.33 \\
7.38\end{array} \quad 5 \mathrm{~min}$ & 250307 & 50061 \\
\hline 7.45 & $\left.\begin{array}{l}7.48 \\
7.58\end{array}\right\} 10 \mathrm{~min}$ & 500681 & 50068 \\
\hline 8.00 & $\left.\begin{array}{l}8.03 \\
8.05\end{array}\right\} 2 \mathrm{~min}$ & 100104 & 50050 \\
\hline
\end{tabular}

し良好な結果を得た ${ }^{8)}$ ここの方法の概要は次のごとくで ある。第 6 図に示すごとく遠心機のタコメーターからの 交番電流を增巾し，これをさらに sine-to-pulse convertor を使用してパルス波になおしこれをスケーラーで 計測する。10 分あるいは 5 分間隔で積算をおこなって, その平均をもとめるとあらゆる変動にかかわらず正しい 本均迴転数がもとめられる。この方式である測定中に行 った迴転数の実澌值を第 1 表に示す。これより明らかな ごとく, 制御は $\pm 0.05 \%$ 程度で良好であることが知ら れる。

\section{$\S 5$ 光 学 系}

超遠心機にとりつけられた光学系は，溶質分子の被降 によって生じた濃度勾配にもとづく属折率あるいは光吸 收係数の变化を利用して, 前者の場合は濃度 $c$ とセル 中の位置 $x$, 後者では $d c / d x$ 之 $x$ の関係を定量的に知 るためのものである。Svedberg が超遠心機を試作活用 しはじめた頁は，主として後者の光吸收係数の変化を利 用する方法が採用されていた。しかし，この方法は一度 写導乾板上の黑化度の变化值すといら中間操作を経過 しなければならず，䟿知のごとく，これは乾板の特性曲 線の変化や，その他種々の因子より災いされることが多 いので, 今日ではほとんど利用されず, もっぱら前者の屈 折率法 (Refraktionsmethode) が採用されている PHYWE 超遠心機においても，やはりこの方法が探用され， いわゆる Philpot-Svensson の “Schlieren” 法と Lamm の“Skalen” 法との変換使用可能のように設計されて いる。

第6 図には “Schlieren” 法の光学系を示してある。 超高圧水銀登 [L]から出た光はコンデンサー [K]に よって水本スリット[HS]上にほぼ平行光束として投 影され，[HS〕の像は[HP〕なるプロゼクションレン ズによって〔S〕なる Schlieren-Spalt の上に結ばれる。 この通路にローター中の測定用セル [Z]があり, この 七ル內の屈折率勾配に応じて, [HS〕なる水平スリトッ の像は勾配の存在する方向に彎曲変位して [S] 上に結 像され，これを[VO]および〔HO]なる 2 枚のレン ズにして乾板 [P] 上に再結像する。もちろんこの途中

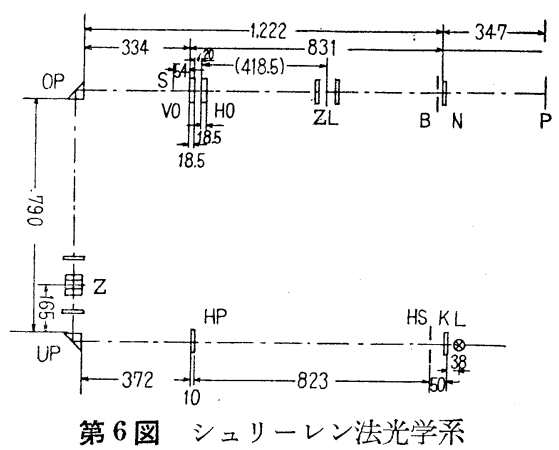

に円筒レンズ [ZL]を扔いて，水本方向に像を桩大す ることは電氣泳動などでっかわれている Tiselius 法と

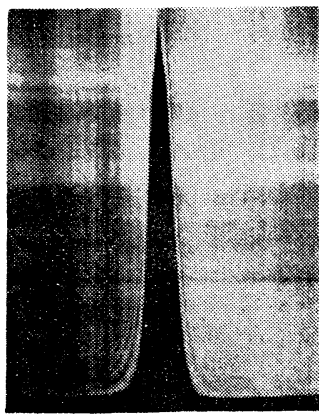

a) Schneide nach Philpot

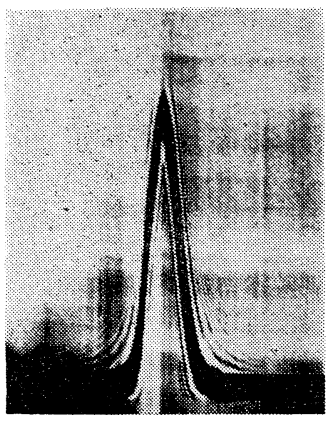

c) Draht nach Svensson

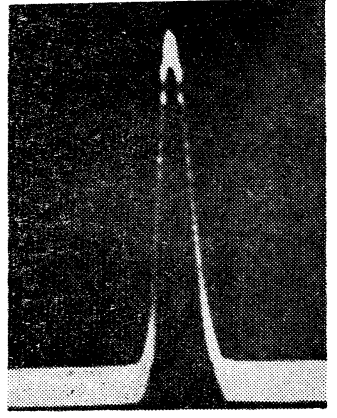

b) Spalt nach Svensson

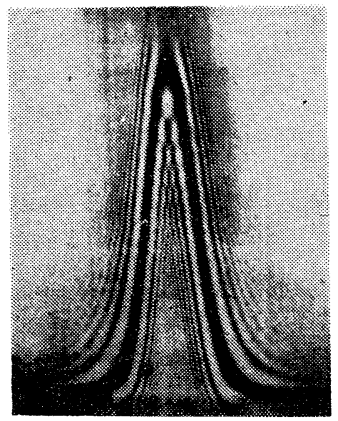

d) Phasenkante nach Kossel, Armbruster und Strohmayer
第 7 図 シュリーレン法による沈降曲線

全く同じである。この光学系の原理自体については, Philpot $^{9}$, Anderson ${ }^{10)}$, Svensson ${ }^{11)}$ の論文および本邦 での参考書などを参照されたい。実際に撮影された写覓 を第7図a,b,c,d にかかげておく。

PHYWE 超遠心機にとりつけられたいま1つの光学 系は, Lamm によってはじめられた “Skalen” 法（ス ケール法）とよばれるものである ${ }^{12)}$ これは溶質の沈降 （または拡散）がセル內におこつているとき，その濃度 勾配にもとづく屈折率変化を，この中を通過する光線の 彎曲の度を利用して空量的に計測せんとするものであ る。すなわち，このような溶液セルの前方に，等間隔で 水平にひかれたスケール（スケールの垂直方向の長さ：2 $\mathrm{cm}$, 各スケール線の間隔：1/5 mm，スケール線の巾： 
第 1 表

\begin{tabular}{|c|c|c|c|}
\hline Time (p.m.) & Time interval & $\begin{array}{l}\text { Total revolu- } \\
\text { tion numbers }\end{array}$ & $\mathrm{rpm}$ \\
\hline 6.45 & $\left.\begin{array}{l}6.48 \\
6.58\end{array}\right\} 10 \mathrm{~min}$ & 500862 & 50086 \\
\hline 7.00 & $\begin{array}{l}7.03110 \mathrm{~min} \\
7.13\end{array}$ & 500805 & 50081 \\
\hline 7.15 & $\left.\begin{array}{l}7.18 \\
7.28\end{array}\right\} 10 \mathrm{~min}$ & 500524 & 50052 \\
\hline 7.30 & $\begin{array}{l}7.33 \\
7.38\end{array} \quad 5 \mathrm{~min}$ & 250307 & 50061 \\
\hline 7.45 & $\left.\begin{array}{l}7.48 \\
7.58\end{array}\right\} 10 \mathrm{~min}$ & 500681 & 50068 \\
\hline 8.00 & $\left.\begin{array}{l}8.03 \\
8.05\end{array}\right\} 2 \mathrm{~min}$ & 100104 & 50050 \\
\hline
\end{tabular}

し良好な結果を得た ${ }^{8)}$ ここの方法の概要は次のごとくで ある。第 6 図に示すごとく遠心機のタコメーターからの 交番電流を增巾し，これをさらに sine-to-pulse convertor を使用してパルス波になおしこれをスケーラーで 計測する。10 分あるいは 5 分間隔で積算をおこなって, その平均をもとめるとあらゆる変動にかかわらず正しい 本均迴転数がもとめられる。この方式である測定中に行 った迴転数の実澌值を第 1 表に示す。これより明らかな ごとく, 制御は $\pm 0.05 \%$ 程度で良好であることが知ら れる。

\section{$\S 5$ 光 学 系}

超遠心機にとりつけられた光学系は，溶質分子の被降 によって生じた濃度勾配にもとづく属折率あるいは光吸 收係数の变化を利用して, 前者の場合は濃度 $c$ とセル 中の位置 $x$, 後者では $d c / d x$ 之 $x$ の関係を定量的に知 るためのものである。Svedberg が超遠心機を試作活用 しはじめた頁は，主として後者の光吸收係数の変化を利 用する方法が採用されていた。しかし，この方法は一度 写導乾板上の黑化度の变化值すといら中間操作を経過 しなければならず，䟿知のごとく，これは乾板の特性曲 線の変化や，その他種々の因子より災いされることが多 いので, 今日ではほとんど利用されず, もっぱら前者の屈 折率法 (Refraktionsmethode) が採用されている PHYWE 超遠心機においても，やはりこの方法が探用され， いわゆる Philpot-Svensson の “Schlieren” 法と Lamm の“Skalen” 法との変換使用可能のように設計されて いる。

第6 図には “Schlieren” 法の光学系を示してある。 超高圧水銀登 [L]から出た光はコンデンサー [K]に よって水本スリット[HS]上にほぼ平行光束として投 影され，[HS〕の像は[HP〕なるプロゼクションレン ズによって〔S〕なる Schlieren-Spalt の上に結ばれる。 この通路にローター中の測定用セル [Z]があり, この 七ル內の屈折率勾配に応じて, [HS〕なる水平スリトッ の像は勾配の存在する方向に彎曲変位して [S] 上に結 像され，これを[VO]および〔HO]なる 2 枚のレン ズにして乾板 [P] 上に再結像する。もちろんこの途中

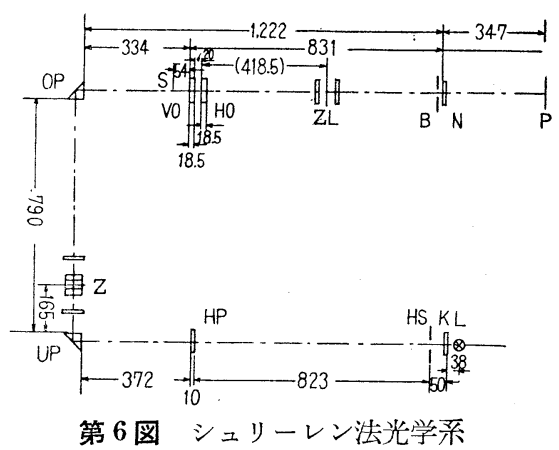

に円筒レンズ [ZL]を扔いて，水本方向に像を桩大す ることは電氣泳動などでっかわれている Tiselius 法と

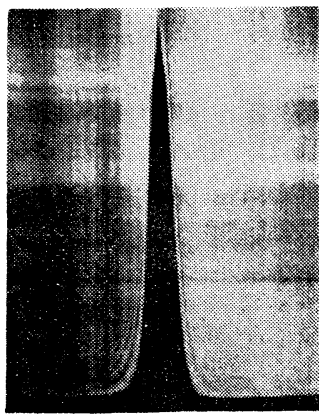

a) Schneide nach Philpot

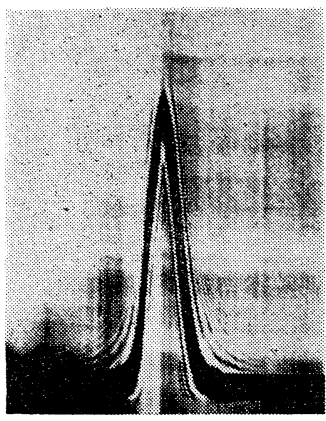

c) Draht nach Svensson

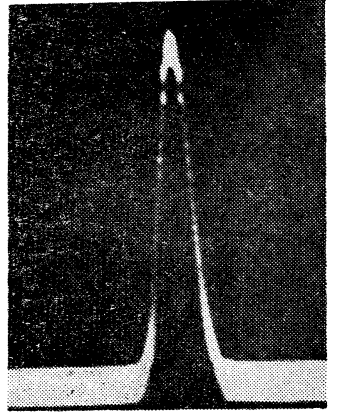

b) Spalt nach Svensson

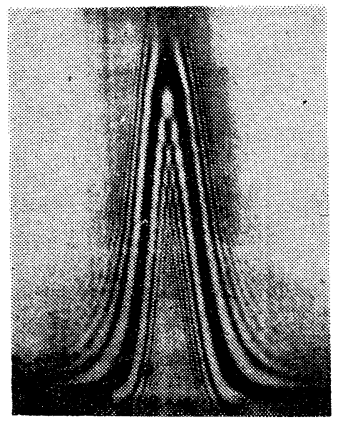

d) Phasenkante nach Kossel, Armbruster und Strohmayer
第 7 図 シュリーレン法による沈降曲線

全く同じである。この光学系の原理自体については, Philpot $^{9}$, Anderson ${ }^{10)}$, Svensson ${ }^{11)}$ の論文および本邦 での参考書などを参照されたい。実際に撮影された写覓 を第7図a,b,c,d にかかげておく。

PHYWE 超遠心機にとりつけられたいま1つの光学 系は, Lamm によってはじめられた “Skalen” 法（ス ケール法）とよばれるものである ${ }^{12)}$ これは溶質の沈降 （または拡散）がセル內におこつているとき，その濃度 勾配にもとづく屈折率変化を，この中を通過する光線の 彎曲の度を利用して空量的に計測せんとするものであ る。すなわち，このような溶液セルの前方に，等間隔で 水平にひかれたスケール（スケールの垂直方向の長さ：2 $\mathrm{cm}$, 各スケール線の間隔：1/5 mm，スケール線の巾： 